\title{
Contents, Vol. 202, 1991
}

\section{No. 1 Laudatio 1}

Original Paper $\cdot$ Travaux originaux $\cdot$ Originalarbeiten

Five-Year Results of the First 159 Consecutive Phakic Chronic Open-Angle Glaucomas

Treated by Argon Laser Trabeculoplasty

Moulin, F.; Le Mer, Y.; Haut, J 3

Function of the Diabetic Retina after Panretinal Argon Laser Photocoagulation. Influence

of the Intensity of the Coagulation Spots

Seiberth, V.; Alexandridis, E 10

Alternation of the q-Switched Nd:YAG Laser and the cw Argon Laser for Tunneling through Organic Material

Schirmer, K.E 18

Refraktionsbestimmung unter Atropinzykloplegie

Hunold, W.; Auffarth, G 26

Technical Procedures and Software for Magnification-Corrected Morphometry of Optic

Disk Photography

Brigatti, L.; Bottom, F.; Miglior, S.; Orzalesi, N 33

Kammerwasserkonzentrationen nichtsteroidaler Antiphlogistika

Strobel, J 38

Zur lokalen Applikation von Indometacin zur Prostaglandinsynthesehemmung am Auge.

Schüttelstudie

Strobel, J 43

Variations du temps normal de réponse du patient pendant la mesure du champ visuel.

Contribution à $\Gamma$ exploration des cellules ganglionnaires

Rouland, J.F.; Hache, J.C 48

A Family with Acquired and Inherited Blue-Yellow Axis

Amiel-Lebigre, F.; Corbé, Ch.; Dufier, J.L.; Archambaud, J.C1 53

Book Review Livre nouveau Buchbesprechung $\quad 60$

Announcements Communications Ankündigungen 52

No. 2 Original Paper - Travaux originaux · Originalarbeiten

Komplizierte okulomotorische Störungen im Urteil des Gutachters

Piper, H.F 61

Elevation tensionnelle oculaire provoquée par un test à $\Gamma$ eau

Warter, G.; Jeannenot, N 75

Choroidal Thickness in Primary Glaucoma

Cristini, G.; Cennamo, G.; Daponte, P 81

Contents III

Quantitative Untersuchungen von Protein- und Zellkonzentrationen in der Vorderkammerbei

Kataraktchirurgie unter Therapie von steroidalen und nichtsteroidalen Antiphlogi-stikaStrobel, J.; Seitz, W.; Tietze, K 86 
Combined Cytochemical Detection of Müller-Cell-Specific Enzyme Activity and Permeability TracersHirata, A.; Kitaoka, T.; Ishigooka, H.; Ueno, S 94

Amplitudes of Visually Evoked Cortical Responses due to Full-Field Stimulation and toStimulation with Four Half-FieldsOrban, D.; Müller, W 100

Optokinetic Nystagmus and Spatial-Selective Attention. An Experimental Study

Crevits, L.; van Vliet, A.G.M 105

Clinicopathologic Case Report · Description clinico-pathologique de cas $\cdot$ Klinisch-

pathologische Fallbeschreibung

Rare Choroidal Tumour Simulating a Malignant Melanoma

Strempel, $1 \quad 110$

Letter to the Editor

Witschel, H 115

Book Reviews Livres nouveaux Buchbesprechungen

Announcement - Communication - Ankündigung 80

No. 3 Original Paper · Travaux originaux $\cdot$ Originalarbeiten

Veränderung des postoperativen Hornhautastigmatismus nach Laserdissektion von Korneoskleralnähten

Giers, U.; Pillunat, L.E 117

Foster Kennedy Syndrome and Optociliary Shunt Vessels in a Patient with an Olfactory

Groove Meningioma

Fukuyama, J.; Hayasaka, S.; Setogawa, T.; Ando, S.; Moritake, K 125

A Case of Parinaud's Syndrome in a Boy with Delayed Puberty

Magli, A.; De Marco, R.; Di Maio, S.; Nunziata, L.; Villani, S.; Calace, P.L 132

Recurrent Mixed Tumor of the Right Lacrimal Gland Causes Acute Contralateral Visual

Loss

Emori, M.; Hayasaka, S.; Setogawa, T.; Miyakuni, Y.; Fukuma, A 138

Low-Vision Aids in Stargardt's Disease

Temel, A.; Kazokogiu, H 142

Colour Vision Testing in Pre-School-Aged Children

Mäntyjärvi, M 147

Ocular Findings in X-Linked Ichthyosis: A Survey on 38 Cases

Costagliola, C; Fabbrocini, G.; Illiano, G.M.P.; Scibelli, G.; Delfíno, M 152

Cytological Evaluation of Adenoviral Follicular Conjunctivitis by Cytobrush

Kobayashi, T.K.; Sato, S.; Tsubota, K.; Takamura, E 156

Extracellular Materials in the Endothelial Meshwork of Organcultured Human Trabecular

Meshwork. Morphologic and Morphometric Study

Urakawa, Y 161

Book Reviews Livres nouveaux — Buchbesprechungen $\quad 169$

IV

Contents

No. 4 Original Paper $\cdot$ Travaux originaux $\cdot$ Originalarbeiten

Extraction of Intraocular Foreign Bodies by Pars plana Vitrectomy. A Retrospective

Study

Camacho, H.; Mejía, L.F 173

Treatment of Pars planitis with Cryotherapy

Okinami, S.; Sunakawa, M.; Arai, I.; Iwaki, M.; Nihira, M.; Ogino, N 
Anterior Lentiplane and Posterior Lenticonus in Two Cases

Deng, C 187

Congenital Glaucoma in Cutis marmorata teleangiectatica congenita

Mayatepek, E.; Krastel, H.; Völcker, H.E.; Pfau, B.; Almasan, K 191

Reversal of Cupping in Experimental Glaucoma

Shirakashi, M.; Nanba, K.; Iwata, K 194

Experimental Studies on the Accumulation of Subretinal Fluid

Tsukahara, Y.; Marmor, M.F 202

Rod Thresholds in Dominantly Inherited Juvenile Optic Atrophy

Elenius, V.; Leinonen, M.; Airas, K 208

Kammerwasserkonzentration von Norfloxacin nach lokaler Applikation

Behrens-Baumann, W 213

Open Noncontrolled Multicenter Long-Term Trial with Ciclosporin in Endogenous Non-

Infectious Uveitis

Secchi, A.G.; De Rosa, C; Pivetti-Pezzi, P.; Rossi, A.; De Molfetta, V.; Tognon, S.;

Latanza, L.; Catarinelli, G.; Scorrano, R.; Bragliani, G.; Zenoni, S.; Delia Casa-

Alberighi, O.; Corbetta, G 217

Announcement Communication Ankündigung

Book Review Livre nouveau Buchbesprechung

Author Index 226

Subject Index 227

S. Karger $\cdot$ Medical and Scientific Publishers

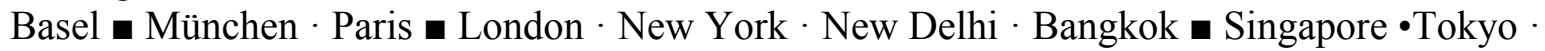

Sydney

Drug Dosage All rights reserved.

The authors and the publisher have exerted every effort No part of this publication may be translated into otherto ensure that drug selection and dosage set forth in this languages, reproduced or utilized in any form or by anytext are in accord with current recommendations and means, electronic or mechanical, including photocopy-practice at the time of publication.

However, in view of ing, recording, microcopying, or by any information stor-ongoing research, changes in government regulations, age and retrieval system, without permission in writingand the constant flow of information relating to drug from the publisher or, in the case of photocopying, directtherapy and drug reactions, the reader is urged to check payment of a specified fee to the Copyright Clearancethe package insert for each drug for any change in indica- Center (see 'Information for Readers and Subscribers'), tions and dosage and for added warnings and precautions. This is particularly important when the recom- (C) Copyright 1991 by

mended agent is a new and/or infrequently employed S. Karger AG, P.O. Box, CH-4009 Basel (Switzerland)

Contents Vol. 202,1991 drug. . Printed in Switzerland on acid-free paper by

Buchdruckerei Friedrich Reinhardt AG

Basel 